\title{
養殖マダイの生理学的研究-III
}

酸化油の消化率ならびに酸化油摄取後の血獎および

㫜すい臓成分の経時変化

\author{
坂口宏海・浜口章
}

(1978 年 11 月 20 日受理)

\section{Physiological Studies on Cultured Red Sea Bream-III}

Digestibility and Changes of Chemical Constituents in Plasma and Hepatopancreas after Feeding of Oxidized Oil.

\author{
Hiromi SAKaguCHI*1 and Akira Hamaguchi*2
}

Red sea bream, Chrysophrys major, were kept on diets containing 11\% of fresh (POV 5) or oxidized pollack residual oil (POV 1,550) for 40 days.

After 20 days of feeding, the digestibility of fat was measured on 20 fish. The rest of the fish were kept for another 20 days on the experimental diets. After 2, 6, 24, 48 and 72 hours following the last feeding, the fish were sacrificed for the measurement of chemical components in the plasma and hepatopancreas.

The digestibility of the fresh oil was $91 \%$, whereas that of the oxidized oil was as low as $77 \%$.

Hyperglycemia was observed in 2 to 24 hours following the administration of the oxidized oil, but elevation of blood glucose level was not significant in fish fed the fresh oil. Intake of the fresh oil was followed by a rise of triglyceride level in the plasma 2 to 6 hours later, but in the case of the oxidized oil its level remained almost unchanged.

Fat content of the hepatopancreas of fish fed the oxidized oil decreased sharply between 2 and 6 hours and then showed a tendency to increase. The administration of the oxidized oil induced remarkable decrease of glycogen in the hepatopancreas.

前報1では，酸化油を含む飼料で飼育したマダイの血 獎中の脂質含量が，正常油を与光た魚のそれより低いこ と起報告した。竹内 ${ }^{2)} コ$ は摽識りノール酸メチール エステル過酸化物を投与した実験で，過酸化物はほとん ぞ吸取されないと報告している。また NisHIDA らろは， 過酸化物含さ脂肪はネズミにおける脂肪の吸収を藷し く阻害することを認めており，マダイに拈いても酸化油 はその書性ととるに脂筫の吸取を抑制するるのと考えら れる。

本報では上部の推測を確かめるために，マダイ若年魚 に前報》の 7 および 10 区の試験飼料に類似した飼料を゙ 投与し，添加油の消化率ならびに飼料摄取後の血漿括よ び肝すい藏中の糖および脂質成分の変化を経時的に調べ た。その結果, 脂肪の消化率や血漿，䀒すい臓中の諸成 分稚加油の性状によつて強く影響されることを認めた ので, ここに報告する。
実 験 方 法

供試魚およひ飼盲法 供試マダイ，Chrysophrys major，は兵庫累立水産試騟場でふ化，飼姢した生後約 5 か月の若年魚 (平均体重 $42 \mathrm{~g}$ ) で, 試䍄開始の前日 市肘の配合飼料を給慨した。

試験飼料は前報1の7および 10 区の飼料を多少改良 したもの（11 拈よび 12 区）である。すなわち米ら゙の

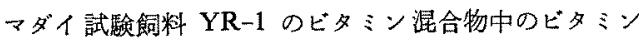
$\mathrm{B}_{2}$ およびEを同量のセルロース粉末で置き換え，また 添加油を $9 \mathrm{~g}$ から $11 \mathrm{~g}$ に增やしてセルロース $2 \mathrm{~g}$ を除 いた。添加油の過酸化物佂は 11 区（前報1７区改良 型) 5, 12 区 (10 区の改良型) 1,550 であつた。 各区の供陚魚数は60 尾とし，20 尾ずつを前報 ${ }^{12}$ と同 じ施設で飼育した。

䬰料は 2 時間ごとに 1 日 5 回与克，每回飽食させた。

*1 長綺大学水産学部 (Faculty of Fisheries, Nagasaki University, Nagasaki 852)

*2 兵庫県立水産試驗埸 (Fisheries Experimental Station of Hyogo Prefecture, Akashi, Hyogo Pref. 673) 
Table 1. Body conditions and digestibility of fat in the red sea bream fed fresh or oxidized oil

\begin{tabular}{ccccc}
\hline Days & Group*1 No. & Body*1 weight $(\mathrm{g})$ & Fatness & Digestivility*3 of fat (\%) \\
\hline 0 & 11 & $40 \pm 4$ & $23.0 \pm 1.1$ & 91.4 \\
& 12 & $41 \pm 6$ & $22.7 \pm 1.3$ & 77.2 \\
& 11 & $46 \pm 8$ & $23.7 \pm 1.0$ & $23.1 \pm 1.4$ \\
\\
40 & 12 & $44 \pm 9$ & $22.4 \pm 2.0$ & $21.5 \pm 1.2$ \\
\end{tabular}

*1 The compositions of test diet for groups No. 11 and 12 were the same as those of test diet for groups No. 7 and 10 in the previous paper, respectively, except that the amounts of fresh and oxidized pollack residual oils were increased to $11 \%$ of the basal diet and that cellulose powders were omitted instead.

*2 mean \pm S.D. $(n=20-35)$

*3 pooled sample of 20 fish.

また飼育期間中の水躍は $18 \sim 20^{\circ} \mathrm{C}$ に保つた。

消化率試騃 試駿魚を上記の条件で 19 日間飼育した 後, 酸化クロムを $1 \%$ 含む䝭料を各区 20 星の魚に 3 日

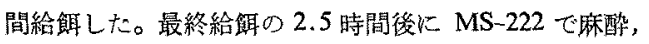
開腹し渴内容物を採取して古川らの方法”で消化率を測 定した。

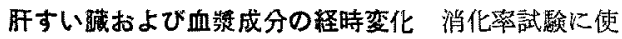

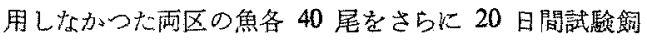

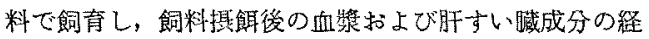
時変化索調心た。供試魚に㤋分析試料採取当日，2時間 ごとに2 回給䬣し，最終給领の $2 ， 6 ， 24,48$ および 72 時間後に各区 8 尾ずつから前報》之同様の方法で血 漿および肝すい臟索採取した。

分析は血算のトリグリセライド，総コレステロール， 遊離脂肪酸およびダルコース含量を市肘の臨床検查用試 薬キット(和光純薬工篻(株))で，また肝すい蔵のダリ ヌーゲンをフンスロン法るで，水分および脂肪含鼠を常 法で測定した。なお分析は血獎成分㑑体別に，肝すい 灆成分は8 尾の混合試料を用いて行なつた。

$$
\text { 結果 }
$$

成長および消化率 正常油を摄取した 11 区のマダイ の体重はかずか増加したが，酸化油投与群 (12区) は はとんど增重しなかつた（Table 1)。肥霂度は雨区間に 差はなかつた。な括埕育期間中に一い死魯はなかつた。

消化率は 11 区 91\%，12区77\% で，酸化油投与群 で多少低い結果が得られた（Table 1)。

肝すい贜の重量比および化学成分の経時変化 給剘直 後の朋すい臓の重量比は両区之も 1.8 前後であつたが, 12 区では24 時間後まで減少し，乙の後安定した(Fig. 1)。一方正常油投与群では 24 時間後までははよんど変 化なく，その嵝に濑減し，終了時には両区の差はなくな stio

掑食 2 時間後の 12 区の急の肝すい臓の脂肪含量は約

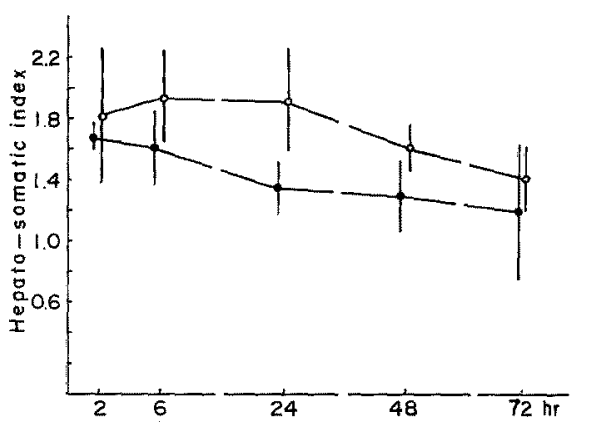

Fig. 1. Effect of oxidized oil on the hepatosomatic index.

Vertical line indicates S.D.

- - oxidized oil, $-\mathrm{O}-$ fresh oil.

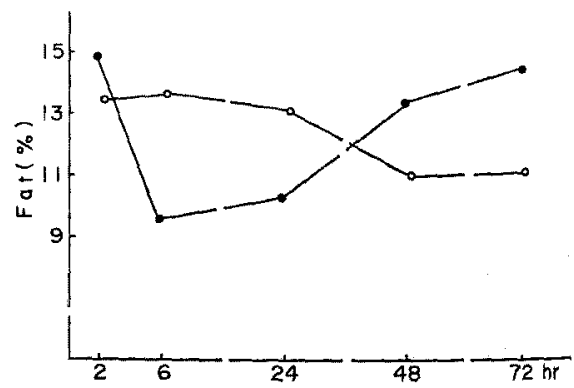

Fig. 2. Effect of oxidized oil on fat in the hepatopancreas.

-O- oxidized oil, $-\mathrm{O}-$ fresh oil.

15\%であつたが，6時間後までは急激に減少し，約 $10 \%$ となつた (Fig. 2)。24 時間後まで同程度の值を持結す るが，その後上异し，終了時には 2 時間後とはとんど 同じレベルをで回復した。11 区では初期の変化は活と んどないが，24〜48 時間後に滅少し，终了㭙の油舍量 は酸化油投与群の約 77\% であつた。 


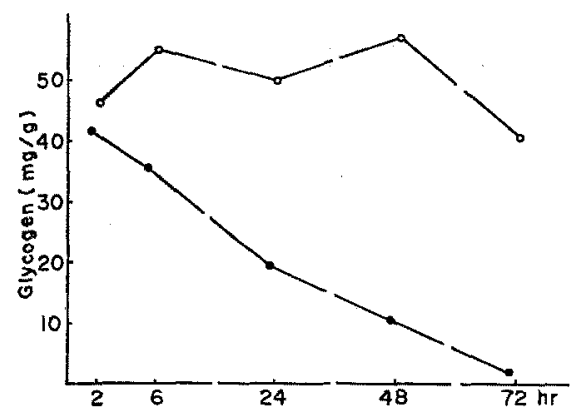

Fig. 3. Effect of oxidized oil on glycogen in the hepatopancreas.

- oxidized oil, - $\mathrm{O}$ - fresh oil.

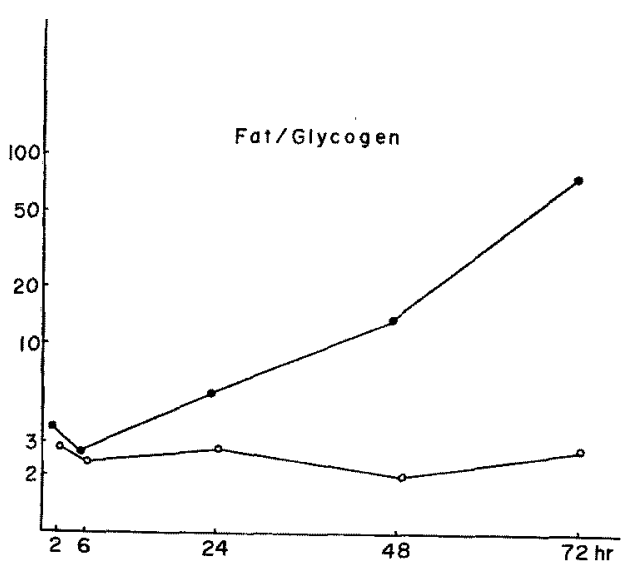

Fig. 4. Effect of oxidized oil on fat/glycogene ratio in the hepatopancreas.

- - oxidized oil, -O- fresh oil.

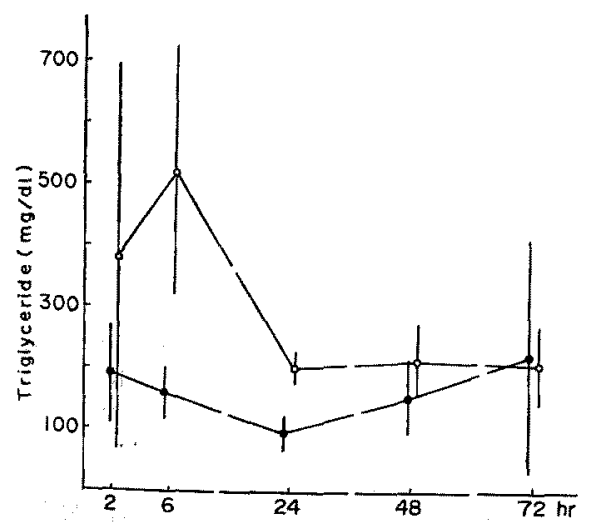

Fig. 5. Effect of oxidized oil on plasma triglyceride.

Symbols are the same as those in Fig. 1.

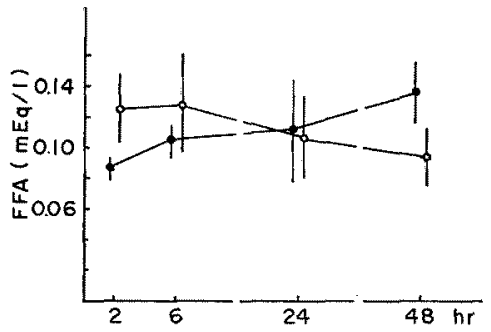

Fig. 6. Effect of oxidized oil on plasma free acid.

Symbols are the same as those in Fig. 1.

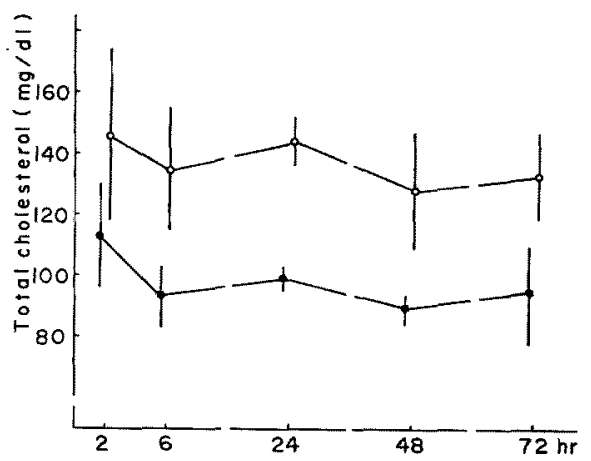

Fig. 7. Effect of oxidized oil on plasma total cholesterol.

Symbols are the same as those in Fig. 1.

正常油摄取魚のグリコーゲン含量は 48 時間以後にわ ずかに減少した（Fig. 3)。他方 12 区では時間の経過と ともに激減し，終了時の含量は $2 \mathrm{mg} / \mathrm{g}$ にすぎなかつた。 脂肪とグリコーゲンの比は Fig. 4 K示したように正常 油投与群では 2〜3であつたが，12 区では時間の経過 とともに上界し，72 時間後には約 73 に達した。

血獎成分の経時変化 正常酒投与魚の血漿トリグリ七 ライド含量は掑飽 $2 \sim 6$ 時間後に $400 \sim 500 \mathrm{mg} / 100 \mathrm{ml}$ と著しく上昇したが，乙の後城少し，24時間以降はに ば一定の含量を維持した（Fig.5)。他方，酸化油を摄 取したマダイでは 24 時間後まで漱減した後增加し, 終 了時には雨区之も同程度の值を示した。

遊離脂肪酸量は 11 区では 6 時間以降わずかずつ減少 したが，12 区では 48 時間後まで上景し続けた（Fig. 6)。

コレステロール含量は両者の間にかなり大きな差が

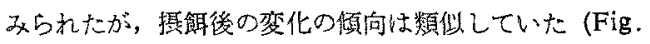
7)。 血糖值にも両者の間に大きな差異が認められた。すな 
坂口・浜口

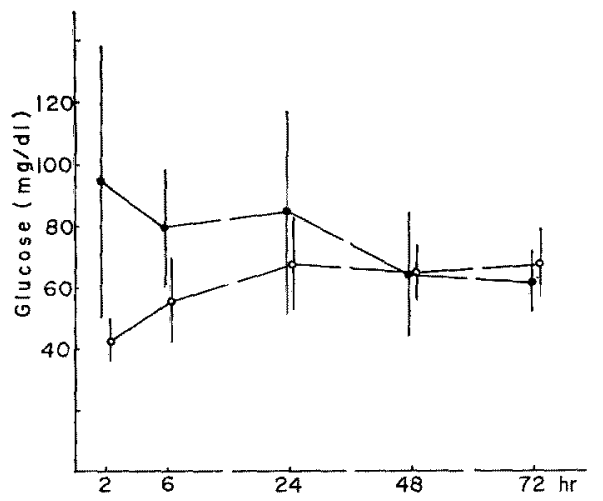

Fig. 8. Effect of oxidized oil on plasma glucose. Symbols are the same as those in Fig. 1.

わち 11 区では 24 時間後まで潮增し, 以後ほとんど変 化しながつたが，12 区では24 時間後まで高血糖が持続 した (Fig. 8)。

\section{考察}

コイ゚で忟与した過酸化物は娃とんど吸収されな い。同様の結果がネズミ゙でも得られている。NISHDA ら によると，六ズミに過酸化物を含む脂肪を与えると 脂肪の消化率が大幅泪害されるという。本寒覧条件下 ではダイに括ける酸化油の消化率は 77\% であり, 正 常油にくらべてかなり低下している (Table 1)。また正 常油摄取魚では, 給䬣 $2 \sim 6$ 時間後に食慨性脂血症を呈 するが，酸化油投与魚にはそのような現象は躍められな かつた (Fig. 5)。これらの結果から，マダイに乱いて も過酸化物が脂肪の吸収を阻害していると考古られる。

ONO らシによると，酸化油を投与したニジスの肝 臓重量比は正常油摂取魚にくらへて高くなつているが, マダイではそのような結果は得られなかつた (Fig. 1)。 この相違が焦種の違いによるものが，あるいは用いた油 の種類や性状など乘窬条件の違いによるすのか明らかで ない。

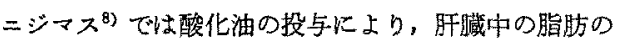
增加点よびダリコーゲンの滅少が認められている。マダ イに和いても酸化油の投与により刵すい贜のグリコーダ ンが著しく減少した。他方脂肪量は 6 24 時間後に減 少した後上景し，48 時間以降忙正常油投与群の含量を 上回つた。また酸化油投与 $40 \sim 50$ 時間後に採取した前 報1)の 9 および 10 区のマダイの肝すい臟の組織には脂 肪変性が認められた（未発表）。したがつてマダイにお いても酸化油の投与が脂肪変性の原因之考えられるが， 酸化油撕取 6〜24時間後にみられた旰すい葴脂肪の一 時的な減少がいかなる機棈汇よるるのか明らかでない。

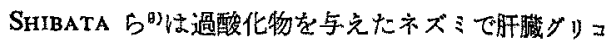
一ゲンの減少と脂肪朋の発現を認め，その原因が過酸化 物による解糖尔酵素の活性上昇之，TCA 回路中の酲素 の不活性化によるすのであるちと推測している。酸化油 を摄取したマダイにも同様の現象が認められたが，これ が SHIBATA らの゙がズミで推測したるのと同様の機序 に上るものか否かは明らかでないので今後検討したい。

酸化油を投与したコイ

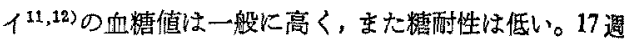

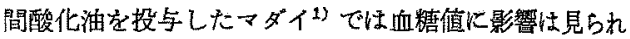
ていない。しかし本柋験で恃酸化油を摄取したマダイの 血糖值は揕餌後 2 24 時間は正常群のそれにくらべて かなり高くなつている (Fig. 8)。したがつてマダイに おいてもコイの塨合と同様に酸化油の投与によつて血糖

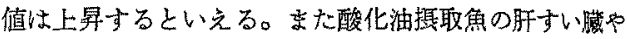
珡臓の組織像に異常が塱められている (未発表)ことな ぞから，本实虑 12 区のマダイにもセコケコイの場合と 同椂に糖尿病棁の症状を是していたとも考克られる。こ れらの点についてはさらに酸化油投与魚の糖豩性などを 調ヘることにより確かめたい。

終りにのぞみ，有益なご助言をいたな゙いた淡水区水産 研究所横手元羲博士, 長崎大学水産学部道津喜衛教授炕

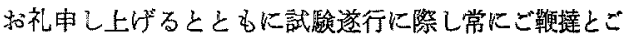
助言をいただいた兵庫県立水座試験場井沢康夫前場長心 喍禹します。

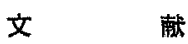

1) 坂口宏海 - 泜口 章：日水誌，45，449-453 (1979).

2) 竹内昌昭：日水誌，38，155-15 (1972).

3) T. NishidA and F.A. Kummerow: J. Lipid Res., 1, 450-458 (1960).

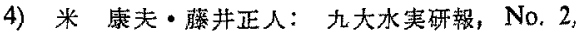
25-32 (1974).

5) 古川厚・塚原宏子：日水誌，32，502-506 (1966).

6) S. Serfter, S. Dayton, B. Novic, and E. MUNTWyler: Arch. Biochem., 25, 191-200 (1950).

7) 衣巻貫輔・柴田宣和・䇣井君枝：ビタミン， 35, 188-194 (1967).

8) T. Ono, F. Nagayama, and T. Masudat J. Tokyo Univ. Fish., 46, 97-109 (1960).

9) N. Shibata, T. Kinumaki, H. Oxuda, and S. Fuju: Agr. Biol. Chem., 37, 1899-1904 (1973)

10）渡辺武 ·土屋孝夫 ·橋本芳郎：日水誌，33， 843-847 (1967).

11) M. Yокоте: Bull. Japan. Soc. Sci. Fish., 36, 1214-1218 (1970).

12) М. Yокоте: Bull. Japan. Soc. Sci. Fish., 36, 1219-1223 (1970). 